\title{
The Interaction of Financial Leverage and Firm's Operational Efficiency
}

\author{
Martha Coleman (Corresponding author) \\ School of Finance and Economics, Jiangsu University, Zhenjiang, China \\ Faculty of Business Studies, Takoradi Technical University, Ghana \\ E-mail: naadjoacole@yahoo.com
}

Justice Mark Baidoo

Faculty of Business Studies, Takoradi Technical University, Ghana

E-mail: badupaa@yahoo.com

Received: December 27, 2019

Accepted: January 17, 2020 Published: February 8, 2020

doi:10.5296/ber.v10i1.16139

URL: https://doi.org/10.5296/ber.v10i1.16139

\begin{abstract}
The study examines the effect of financial leverage on operational efficiency. This study used a panel data of 102 non-financial companies listed on Nigeria and Ghana stock exchange for the period 2012 - 2016. It was revealed that there is an S-curve relationship between financial leverage and working capital management and cash holding. Also there is a significant moderating effect on the relationship between internationalization and dividend payout. This implies that firms that are involved in international activities are highly concerned with having borrowing as part of their capital structure than solely operating with owners' capital which might be the case of most domestic firms. Relationship between financial leverage and working capital management and cash holding is considered to be non-monotonic which gives management insight of choosing the right leverage management policy to achieve desired goal.
\end{abstract}

Keywords: Financial leverage, Working capital management, Cash holding, Internationalization

\section{Introduction}

Working capital management has been one of the key areas of determine the operational efficiency and increase/decrease in profitability and growth of firms and important tool for 
gaining competitive advantage (Ukaegbu, 2014). Firms' value greatly depends on the working capital policy for efficient and effective management of resources invested by the shareholders. The ability of a firm to raise funds to fund the gap between short and long term financial needs is considers as working capital management (current assets and current liabilities). The relationship between borrowed and owner's investment in the capital structure of an organization is determine by financial leverage. It includes preferred equity, common equity, and debt that are used to finance the firm's operations, assets and financial growth (Goel, Chadha and Sharma, 2015). Firms need external debt in financing their operation activities, solely depending on equity poses high risk of not meeting market demands. Therefore, the question is what is the most efficient way of leverage for a firm, high or low? Higher financial leverage decrease firm value by increasing bankruptcy risk. A higher leverage prevents firms from having access to cheaper sources of funds (Baños-Caballero, García-Teruel and Martínez-Solano, 2014). In other words, high leverage forces firms to use internal resources to repay the increased leverage and in turn reduce the internal fund to manage the operational needs of the firm for which working capital is the key (Baños-Caballero, García-Teruel and Martínez-Solano, 2014). Whiles firms with lower leverage are more likely to utilize the benefits of having a longer cash conversion cycle such as increasing profitability and stock returns coupled with higher growth rate through reduction in supply costs, avoidance sales loss, boosting sales via offering generous credit policies, and getting early discounts from suppliers (Dalci and Ozyapici, 2018). Hence, management of working capital is essential to the growth and survival businesses.

Sub-Sahara Africa countries have experienced various economic conditions; growth, decline or stagnated condition. These economic conditions affect the individual industrial performance either direct or indirect. The report of World Economic and Financial Survey (2017) indicates that in 2016 in Sub-Sahara Africa growth reached an average of 1.4 percent which represent the lowest in two decades. There was a dropped in economic activity Nigeria having an estimated of $1 \frac{1}{2} \%$, CEMAC countries $3 / 4 \%$, and a sharp decline in South Sudan with an estimate of $133 \%$, with other economies remaining stagnate like Angola. There is high level of economic crises in resource-intensive countries with unrest political uncertainty (South Africa), weak fundamentals (Ghana), and severe droughts (Lesotho, Malawi, Zambia, and Zimbabwe) accompanied by weak commodity prices in these countries. Sub-Sahara African countries accessing international capital markets remained unachieved because of the economic downturn with only Ghana and Nigeria in the West Africa were able to tap the market early 2016. Economies in this region are experiencing deterioration in economic activities accompanied by huge fiscal deficits due to depth of the economic shock. This resulted in declined performance of firms located in resource-exporting countries like Nigeria and Ghana. This condition affected the stock returns of firms located in this region, with some making no returns on stock and few paying dividend to shareholders. The performance of firms listed on Ghana stock exchange has been unstable with some experienced negative or no stock returns. According to the annual financial report none of 20 non-financial firm listed on Ghana had an increasing stock returns for the period 2011 - 2016 as shown in Figure 1. Firms in Nigeria went through period of recession; this slows down the economy, they are still in the recovery stage. 


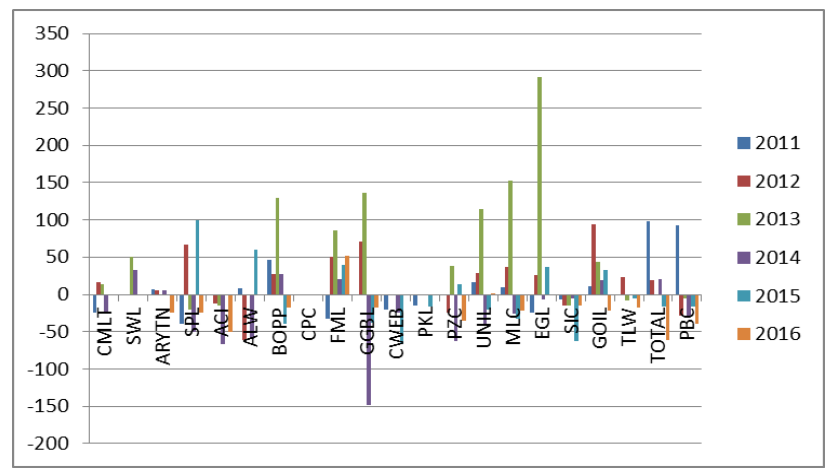

Figure 1. Stock Returns of non-financial firms listed on Ghana stock exchange

Attention has been drawn to the effective management of short term assets and liabilities management in order to reduce the impact of economic shocks in the period of economic uncertainty. Hence, efficient working capital is critical for non-financial firm's ability to cope with weak economic uncertainty. Liquidity management is important for non-financial firms in both boom and lean season. The fundamental part of corporate strategy is the efficient management of working capital for shareholders' value maximization. The optimal level of working capital is of necessity for value maximization (Afza \& Nazir, 2007). Basically, firms invest more in current assets with less liquidity depending on short term debt and cash flows variations. Efficient working capital management will allow firms to redeploy underutilized of firm's resources to higher-valued use in which could heighten of firm's performance(Aktas, Croci, \& Petmezas, 2015). Business entities in all business cycle manage and monitor their working capital to enhance optimization of the resources invested in the firm in order to achieve efficiency and performance in every aspect of the business; obtaining greater market share and growth for shareholder value maximization. Short term assets and liabilities determine the management efficiency of the firm; inefficient working capital management leads to crises situation for firms in both short and long run with low firm performance and impede a firm's ability to keep to its operation and further expose it to the risk of bankruptcy.

Some studies for example Casey and O'Toole, (2014) focused on the relationship between trade credit policy and the supply of bank loans in the periods of financial crisis while Tsuruta (2019) investigated firm performance in the season of financial recession. This study extends the research of Vithessonthi and Tongurai (2015) by examining the effect of financial leverage on working capital management. Further analysis was undertaking to assess the moderating effect of internationalization on the relationship between financial leverage and working capital management. This study extend the research of Vithessonthi and Tongurai (2015) examines the effect of financial leverage on working capital management with moderating effect of internationalization. From the study it was revealed that there is a strong negative relationship between financial leverage and working capital both domestic and international firms and internationalization positively moderate the relationship between financial leverage and working capital management. 


\section{Literature Review}

\subsection{Working Capital and Financial Leverage}

Many companies struggle with the management of their operational activities in the recession period. Reduction in demand increasingly exhausts the working capital of firms. Many firm customers began to experience economic distress because of that there is delayed in the payment for goods and services leading to high trade receivables, low trade payables (Boissay and Gropp, 2013) and decrease in purchases (Tsuruta, 2019). Similarly in the work of Chen \& Kieschnick (2018) they discovered that a dollar invested in net operating capital is less important than a dollar in cash holding for average firm. It was also discovered that an increase in operating working capital has influence on firm future sales expectation, its debt loads, its financial distress, and its bankruptcy risk. Therefore, the value of a dollar extended to customers has significant impact on the shareholders' wealth than a dollar investment in inventories for average firm. Thereby the management of working capital is of much important to all sizes of firm in order to operate in an optimal level to reduce the impact of economic shocks in the crises economic period. Changes in the economic conditions affect investment in working capital. In recession period, premium is placed on liquidity as well as striking on optimum position of working capital. Financial distress firms react differently in recession than nonfinancial distress firms. Financial constraints firm has their optimal level of working capital lower than nonfinancial constraint firm. This may be period where the growth of firms either becomes stagnant or declines considerably and there is cash flow constraint. There is longer debt collection periods and increase in inventories due to reduction in sales. Therefore firms need to increase its investment in working capital in order to operate efficiently (Enqvist, Graham, \& Nikkinen, 2014) which calls for higher liquidity level.

Therefore, investment in working capital depends on the financing conditions of a firm. Firms exposed to greater financing capacity and access to capital market invest more in working capital and keeps higher level working capital than firms that are financially distressed (Hill, Kelly, and Highfield, 2010). This is known in theoretical models of Einarsson and Marquis (2001) and Braun and Larrain (2005). Also Fernandez-Corugedo et al. (2011) developed a dynamic stochastic general equilibrium (DSGE) model that shows how economic shocks lead to adjustment of working capital positions by firms. The findings of Dalci \& Ozyapici (2018) suggest that that financial leverage influences the relationship between the cash conversion cycle and profitability, the degree of financial leverage is an important indicator to be considered by corporate managers. Although extensive research has been undertaken in assessing impact of working capital management on financial performance (eg. Afza \& Nazir, 2007; Aktas, Croci, \& Petmezas, 2015), this study investigates on the impact of financial leverage on working capital management which has received less attention in research.

\subsection{Hypothesis Development}

\subsubsection{Financial Leverage, Working Capital Management and Internationalization}

Most firms in the developing economies have greater portion of their operations financed by 
short term liabilities. According to Ezeoha (2008) as much as $91.4 \%$ of the total finances of Nigerian-quoted firms are of short-term liabilities, with just $8.6 \%$ constituting long-term liabilities. International firms have greater access to capital market than the domestic firm, influences the expansion and growth of international firms. In the study of Vithessonthi and Tongurai (2015) found that effect of leverage on performance is negative for the domestically-oriented firms. Effect of leverage on performance is positive for the internationally-oriented firms. In other words, firms with high leverage are more exposed to expensive borrowing with high interest and opportunity cost as cash conversion cycle gets longer, firms with low leverage are more likely to utilize the benefits of having a longer cash conversion cycle such as increasing profitability through reducing supply costs, avoiding loss of sales due to being out of stock, boosting sales via offering generous credit policies, and getting early discounts from suppliers (Dalci and Ozyapici, 2018). Also firms with low leverage are less likely to be influenced from negative effects of long cash conversion cycles. Nevertheless, firms which have a low amount of external debt in their capital structure are better able to finance the increased working capital either with internal capital sources or with cheaper external debt (Mathuva, 2014). In this vein, as leverage gets lower, the cost of financing increased working capital falls down. Goel, Chadha and Sharma (2015) assert that financial leverage is positively correlated with the cash conversion cycle (CCC) and financial leverage has significant effect on current ratio and has a positive relation. Financial leverage has negative relationship with the liquidity measure. As the firm becomes more leveraged, it also tends to become more liquid. This indicates that the funds raised from debt are used by firms to finance their current assets and pay off their current liabilities. This is in agreement with the conservative approach of working capital where long term funds are used to finance short term assets. The study of Kaupelyte \& Mscichauskas (2016) finds negative relationship between financial leverage and the working capital ratio. Base on the above, we hypothesize that there is significant negative relationship between financial leverage and working capital and internationalization the relationship between financial leverage and working capital.

H1 Internationalization negatively moderates the relationship between financial leverage and working capital management than domestic firm.

\subsubsection{Financial Leverage and Cash Holdings}

Cash holdings is seen as highly liquid and measures how firms respond to prompt payment of bills outstanding. As least profitable as it is, it is important element which determines the liquidity state of an organization. For company or firms to increase sales, it is expedient for them to build cash reserves so as to have positive cash flow. A good economic condition does not call for a larger cash reserve due to higher opportunity cost accompanied by it, whereas economic downturns will call for extra cash holdings to meet uncertainty occurrences. Therefore, financial leverage is one of the components of financial resources which influence the cash reserves of any organization. Studies have confirmed that cash holding is affected by leverage (Gill and Biger, 2013; Ferreira and Vilela, 2004). Firms that have ability to raise funds externally as part of their capital structure as in the case of international firms has limited need of cash reserves (Ferreira and Vilela, 2004; Al-najjar and Ã, 2011). Therefore, firms involve in internal activities prefer to hold less cash reserve as they are surrounded with 
many avenues to raise funds if the any arises. Base on the above we hypothesize the following;

$\mathrm{H} 2$ there is a positive relationship between financial leverage and cash holdings of domestic and international firms

\section{Methodology}

This study used a panel data of nonfinancial companies listed on Nigeria and Ghana stock exchange for the period 2012 - 2016. Data extracted from the annual financial report. Companies with serious missing annual financial data were dropped given a total of 103 companies from both countries (Nigeria and Ghana) with total observation for the study was 510. We test the hypothesis discuss in 2.1 and research question that financial leverage influence working capital management with the moderating effect of internationalization.

\subsection{Dependent Variable}

The dependent variable for the study was lag of working capital which is calculated by subtracting total current liabilities from total current assets consistent with Enqvist, Graham and Nikkinen (2014). Cash holding is measured as cash plus cash equivalent minus current debts divided by total revenue following the research of Mun and Jang (2015).

\subsection{Independent Variable}

The independent variable for the study were leverage (LEVE) which is measured by total liabilities divided by total assets, income level (INCM) is measured as total revenue divided by total assets, debt ratio (DEBTR) is measured as total debts (short and long) divided by total assets consistent with Baños-Caballero, García-Teruel and Martínez-Solano (2014), Sivathaasan et al. (2016), Al-najjar and Clark (2017). Internationalization which is a dummy variable is measured as ' 1 ' for firms involve in international activities like export and import of product, ' 0 ' for otherwise consistent with the study of Angulo-ruiz et al. (2018), dividend payout (DIVPO) was measured as ' 1 ' for firms which have paid dividend within the study period ' 0 ' for otherwise following the research of Gill and Biger (2013).

\subsection{Control Variables}

The control variable used for the study may have influence on the result of effect of corporate governance on working capital management. Firm size (FSIZE) is measured by lag of firms total assets; firm age (FAGE) measured as log of the numbers of years the firm has been listed on stock exchange consistent with Paniagua et al. (2018); inflation rate (INFL) measured as realized inflation rate over the next year following Boubakri and Saffar (2016).

\section{Econometric model}

Linear Model

$$
L N W C=\beta_{0}+\beta_{1}(\mathrm{LEVE})_{i t}+\beta_{2}(\mathrm{DEBTR})_{i t}+\beta_{3}(\mathrm{INT})_{i t}+\beta_{4}(\mathrm{DIVPO})_{i t}+\beta_{5}(\mathrm{INCM})_{i t}+\beta_{6}(\mathrm{FAGE})_{i t}+\beta_{7}(\mathrm{FSZE})_{i t}+\beta_{8}(\mathrm{INFL})_{i t}+\varepsilon_{i t}
$$

Cubic Model 
$L N W C=\beta_{0}+\beta_{1}(\mathrm{LEVE})_{i t}+\beta_{2}(\mathrm{LEVE})_{i t}^{2}+\beta_{3}(\mathrm{DEBTR})_{i t}+\beta_{4}(\mathrm{INT})_{i t}+\beta_{5}(\mathrm{DIVPO})_{i t}+\beta_{6}(\mathrm{INCM})_{i t}+\beta_{7}(\mathrm{FAGE})_{i t}+\beta_{8}(\mathrm{FSZE})_{i t}+\beta_{9}(\mathrm{INFL})_{i t}+\varepsilon_{i t}$

Quadratic Model

$L N W C=\beta_{0}+\beta_{1}(\mathrm{LEVE})_{i t}+\beta_{2}(\mathrm{LEVE})_{i t}^{2}+\beta_{3}(\mathrm{LEVE})_{i t}^{3}+\beta_{4}\left(\mathrm{DEBTR}_{i t}+\beta_{5}(\mathrm{NTT})_{i t}+\beta_{6}(\mathrm{DIVPO})_{i t}+\beta_{7}\left(\mathrm{INCM}_{i t}+\beta_{8}(\mathrm{FAGE})_{i t}+\beta_{9}(\mathrm{FSZE})_{i t}+\beta_{10}\left(\mathrm{INFL}_{i t}+\varepsilon_{i t}\right.\right.\right.$

Interactive Model

$$
\begin{aligned}
& L N W C=\beta_{0}+\beta_{1}(\mathrm{LEVE})_{i t}+\beta_{2}(\mathrm{DEBTR})_{i t}+\beta_{3}(\mathrm{INT})_{i t}+\beta_{4}(\mathrm{LEVE})_{i t} \times\left(\mathrm{INT}_{i t}+\beta_{5}(\mathrm{DIVPO})_{i t}+\beta_{6}\left(\mathrm{INCM}_{i t}+\beta_{7}(\mathrm{FAGE})_{i t}+\beta_{8}(\mathrm{FSZE})_{i t}+\beta_{9}(\mathrm{INFL})_{i t}+\varepsilon_{i t}\right.\right. \\
& L N W C=\beta_{0}+\beta_{1}(\mathrm{LEVE})_{i t}+\beta_{2}\left(\mathrm{DEBTR}_{i_{i t}}+\beta_{3}(\mathrm{INT})_{i t}+\beta_{4}\left(\mathrm{DIVPO}_{i t}+\beta_{5}\left(\mathrm{LEVE}_{i_{i t}} \times(\mathrm{DIVPO})_{i t}+\beta_{6}\left(\mathrm{INCM}_{i t}+\beta_{7}(\mathrm{FAGE})_{i t}+\beta_{8}\left(\mathrm{FSZE}_{i_{i t}}+\beta_{9}(\mathrm{INFL})_{i t}+\varepsilon_{i t}\right.\right.\right.\right.\right. \\
& C A S H O=\beta_{0}+\beta_{1}\left(\mathrm{LEVE}_{i_{i t}}+\beta_{2}\left(\mathrm{DEBTR}_{i t}+\beta_{3}(\mathrm{INT})_{i t}+\beta_{4}(\mathrm{DPO})_{i t}+\beta_{5}\left(\mathrm{LEVE}_{i_{i t}} \times\left(\mathrm{DIVPO}_{i t}+\beta_{6}\left(\mathrm{INCM}_{)_{i t}}+\beta_{7}\left(\mathrm{FAGE}_{i t}+\beta_{8}(\mathrm{FSZE})_{i t}+\beta_{9}(\mathrm{INFL})_{i t}+\varepsilon_{i t}\right.\right.\right.\right.\right.\right. \\
& C A S H O=\beta_{0}+\beta_{1}(\mathrm{LEVE})_{i t}+\beta_{2}\left(\mathrm{DEBTR}_{)_{i t}}+\beta_{3}(\mathrm{INT})_{i t}+\beta_{4}(\mathrm{DIVPO})_{i t}+\beta_{5}(\mathrm{LEVE})_{i t} \times\left(\mathrm{INT}_{i t}+\beta_{6}\left(\mathrm{INCM}_{i t}+\beta_{7}(\mathrm{FAGE})_{i t}+\beta_{8}(\mathrm{FSZE})_{i t}+\beta_{9}(\mathrm{INFL})_{i t}+\varepsilon_{i t}\right.\right.\right. \\
& C A S H O=\beta_{0}+\beta_{1}(\mathrm{LEVE})_{i t}+\beta_{2}\left(\mathrm{DEBTR}_{i t}+\beta_{3}(\mathrm{INT})_{i t}+\beta_{4}(\mathrm{DIVPO})_{i t}+\beta_{5}\left(\mathrm{INCM}_{i t}+\beta_{6}(\mathrm{LEVE})_{i t} \times\left(\mathrm{INCM}_{)_{i t}}+\beta_{7}(\mathrm{FAGE})_{i t}+\beta_{8}(\mathrm{FSZE})_{i t}+\beta_{9}(\mathrm{INFL})_{i t}+\varepsilon_{i t}\right.\right.\right.
\end{aligned}
$$

\section{GMM Model}

$L N W C=\beta_{0}+\beta_{1}(\mathrm{LNWC})_{i, t-1}+\beta_{2}(\mathrm{LEVE})_{i t}+\beta_{3}(\mathrm{DEBTR})_{i t}+\beta_{4}(\mathrm{NNT})_{i t}+\beta_{5}(\mathrm{DIVPO})_{i t}+\beta_{6}(\mathrm{INCM})_{i t}+\beta_{7}(\mathrm{FAGE})_{i t}+\beta_{8}(\mathrm{FSZE})_{i t}+\beta_{9}(\mathrm{NNLL})_{i t}+\varepsilon_{i t}$

\section{Analysis}

Table 1 present the descriptive statistics of the variables showing averages and standard deviation values. The dependent variable working capital (LNWC) has average of is 3.337 with a standard deviation of 2.9, the average of cash holdings (CASHO) is -1.08. An average firm has leverage (LEVE) of 0.798 with standard deviation of 1.536 this implies that firms in both countries (Nigeria and Ghana) are overleverage which causes firms to be exposed to expensive external borrowing with high interest rate and this prolongs the cash conversion cycle and subsequently affect the revenue generation (Dalci and Ozyapici, 2018). The average of internationalization is 0.225 meaning that $22.5 \%$ of the listed firms are involve in international activities implying that they operate most of the listed firms operate locally which limited firms to other external source of funds and also not expose to new capabilities, knowledge and resources which will enhance profitability and grow (Vithessonthi and Tongurai, 2015). An average firm has debts ratio of 15.7, income to total assets ratio (INCM) of 0.2635 , dividend payout (DIVPO) of 0.71 . Also the average firm's age is 1.32 whiles size was 6.66 , and inflation produced 0.112 .

Table 2 is the correlation of the main variables. It could be seen that leverage has a negative correlation with working capital as well as debts ratio. All the independent variables correlate positively with working capital except internationalization and debts ratio. With the control variables all correlate positively with working capital except inflation which has a negative correlation. This gives a proof of the variables not having multicollinearity. To further confirm that there exist no multicollinearity, Vector inflation factor was conducted. All the variables are having VIF value less than 2 which is far from 5 as started by Studenmund, (1997) meaning that correlation coefficients among variables are low; therefore, there is no multicollinearity problems in our model.

Table 3 shows regression result for the equation 1-5. From model 1 indicates the linear regression showing that leverage (LEVE) significantly correlates negatively with $\log$ of working capital (LNWC) at $1 \%$ implies that the efficiency of working capital management 
depends on the leverage position of the firm. Other independents variables debts ratio (DEBTR), internationalization (INT) and income level (INCM) were significant at 5\%. Dividend payout (DIVPO) was significant at $1 \%$ implying that management of working capital greatly contributes to the maximization of shareholders' worth. All the control variables were not significant. Model 2 tests the quadratic relationship of leverage (LEVE) and INT with other independents variables on log working capital (LNWC). Results of the quadratic model indicate a significant positive relationship between LEVE2 and LNWC. This result shows that there is curvilinear relationship between LEVE and LNWC. The negative sign of LEVE in the linear model and the positive sign in the quadratic model imply that introduction of debt component in the running of the activities of the firm's calls for additional financial expenses which the benefits is not seen at the early age of operation but as time lapse better management of debt and other resources producing efficiency working capital management thereby enhancing shareholders' wealth. Model 3 tests the sigmoid or S-curve relationship between LEVE and working capital management. The significant negative coefficient of LEVE3 implies that an S-curve relationship exists. This is supported by an increase in Adjusted R2 from 19.6\% in Model 2 to 21.6\% Model 3. Model 4 tests the interaction effects of LEVE and INT on working capital. The significant negative coefficient of LEVE $x$ INT indicates that the relationship between leverage and working capital is moderated by internationalization. Implying that as firms involves in international activities (import and export) their leverage increases, this is because these firms have multiple external debt source which are used to finance the operation of the firm thereby manage their internal operations with external debt. All the control variables in all the models are not significant. For model 5 shows a significant and negative interaction of LEVE and DIVIPO on working capital management. Model 6 present the result of GMM regression which is more robust than the OLS. It was discovered that LEVE and DEBTR had negative and significant impact on LNWC at $1 \%$ and 5\% respectively. This shows that an increase in the financial leverage of the firm reduces working capital management. Also DIVI and INCOM had positive and significant effect on LNWC all at $1 \%$. This implies that successful and profitable firms manage their working capital well which then enhances the payment of dividend to shareholders.

Table 4 present the effect of leverage and other independents variables on working capital and cash holdings (CASHO) of Domestic firms. From model 1 indicates the linear regression showing that leverage (LEVE) significantly correlates negatively with working capital (LNWC) at $1 \%$ implies that the efficiency of working capital management depends on the leverage position of the firm. The leverage position of a firm influences the cash conversion cycle (CCC) and liquidity ratios, the study is consistent with Goel, Chadha and Sharma (2015), Dalci and Ozyapici (2018) and Gill and Biger (2013). Other independents variables debts ratio (DEBTR), income level (INCM) and Dividend payout (DIVIPO) was significant at $10 \%, 1 \%$ and $1 \%$. Control variables were non-significant age of firm (FAGE) which is significance at $1 \%$. Model 2 tests the linear relationship of leverage (LEVE) and cash rate (CASHR). There is significant negative relationship between LEVE and CASHO at $1 \%$, implies that domestic firms have high cash reserve which is used to finance the operational activities because of the limited sources for external borrowing (Ferreira and Vilela, 2004; 
Al-najjar and $\tilde{A}, 2011)$. Also INCM and FAGE were significant at $1 \%$ and $10 \%$ respectively. Model 3 tests the interaction effects of LEVE and DIVIPO on CASHO. There is non-significant relationship of LEVE x DIVIPO on working capital in Model 5 indicating that the relationship between leverage and cash rate is not moderated by dividend payout of a domestic firms. Implies that firms having positive and high cash reserves influence prompt payment of dividend to shareholders. Model 4 tests the interaction effects of LEVE and INCM on CASHO. The significant positive coefficient of LEVE $x$ INCM indicates that the relationship between leverage and cash holding is moderated by income level of a domestic firm. The higher the income level and leverage the higher the cash holding of a domestic firm. The main component of income is the ability of the firm to generate substantial revenue and these calls for efficient utilization of working capital and leverage to shorten cash conversion cycle. Firm with high leverage has longer CCC than firm with shorter CCC (Mathuva, 2014; Goel, Chadha and Sharma, 2015). This implies that leverage affect cash reserves, therefore for firms to increase cash reserve it beholds on them to generate substantial revenue. Model 5 tests the interaction effects of LEVE and SIZE on CASHO. The significant negative coefficient of LEVE x SIZE indicates that the relationship between leverage and cash rate is moderated by firm's size of a domestic firm. The size of the firm determines the size of leverage, the bigger the firm size the larger the leverage component consistent with Altaf and Shah (2016), Ezeoha (2008).

Table 5 presents the effect of leverage and other independents variables on working capital and cash holdings of International firms. From model 1 indicates the linear regression showing that leverage (LEVE) significantly correlates negatively with log of working capital (LNWC) at $10 \%$ implies that the efficiency of working capital management depends on the leverage position of international firm. implying that an increase in leverage reduces working capital management (liquidity ratio, CCC, etc) (Gill, 2015). Income level (INCM) was significant at 5\%. Internationalization (either inward internationalization or outward internationalization orientation) gives the firms the opportunity of having better access to a larger network in which they can obtain resources (Vithessonthi and Tongurai, 2015) which may be used in financing the short term operational needs of the firm. Control variables were non-significant. Model 2 tests the linear relationship of leverage (LEVE) and cash holding (CASHO); there is significant negative relationship between LEVE and CASHO at 1\% which implies that financial leverage has influence on cash reserve; as leverage increase cash holding reduces as is seen as having non-monotonic relationship (Guney, Ozkan and Ozkan, 2007). Firms that have ability to raise funds externally as part of their capital structure as in the case of international firms has limited need of cash reserves (Ferreira and Vilela, 2004; Al-najjar and $\tilde{A}, 2011$ ). Also INCOML and FAGE were significant at 1\%. Model 3 tests the interaction effects of LEVE and DIVPO on CASHO. There is significant relationship of LEVE $x$ DIVIPO indicates that the relationship between leverage and cash holding is moderated by dividend payout (DIVIPO) of international firm. This is consistent with the study of Al-najjar and $\tilde{A}$ (2011) firms that pay dividends can raise funds at lower costs compared to those that do not, thereby reducing their need to hold cash. Thus, leverage is expected to be negatively related to cash holdings. Model 4 tests the interaction effects of LEVE and INCM on CASHO. The non-significant coefficient of LEVE x INCM indicates 
that the relationship between leverage and cash holding is not moderated by income level of international firm. Model 5 tests the interaction effects of LEVE and SIZE on CASHO. The non-significant coefficient of LEVE x SIZE indicates that there is no relationship between leverage and cash rate is not moderated by SIZE of international firm. this reject the study of Al-najjar and Clark (2017).

Table 1. Descriptive Statistics

\begin{tabular}{|l|l|l|l|l|l|}
\hline variable & Observation & Mean & Std. Dev & Min & Max \\
\hline LNWC & 510 & 3.33753 & 2.944644 & 0 & 7.80591 \\
\hline LEVE & 510 & 0.798303 & 1.536603 & -0.46993 & 6.97722 \\
\hline DEBTR & 510 & 5.78375 & 3.2355 & 0 & 8.243 \\
\hline INT & 510 & 0.22549 & 0.418315 & 0 & 1 \\
\hline DIVIPO & 510 & 0.715686 & 0.45153 & 0 & 1 \\
\hline CASHO & 510 & -1.08097 & 5.43682 & -105.316 & 0.943265 \\
\hline INCM & 510 & 23.308 & 12.573 & 1 & 51 \\
\hline LNAGE & 510 & 1.3287 & 0.269257 & 0.69897 & 1.70757 \\
\hline SIZE & 510 & 6.662087 & 1.132862 & 3.256426 & 9.184097 \\
\hline INFL & 510 & 0.112669 & 0.03342 & 0.0707 & 0.1745 \\
\hline
\end{tabular}

Table 2. Correlation of Main Variables

\begin{tabular}{|l|l|l|l|l|l|l|l|l|l|l|}
\hline & LNWC & LEVE & DEBTR & INT & DIVIPO & CASHO & INCM & LNAGE & SIZE & INFL \\
\hline LNWC & 1 & & & & & & & & & \\
\hline LEVE & -0.1821 & 1 & & & & & & & & \\
\hline DEBTR & -0.1532 & 0.0899 & 1 & & & & & & & \\
\hline INT & -0.0064 & -0.0171 & -0.0926 & 1 & & & & & & \\
\hline DIVIPO & 0.3597 & -0.2089 & -0.1702 & 0.1914 & 1 & & & & & \\
\hline CASHO & 0.176 & -0.0916 & -0.0222 & 0.0772 & 0.2237 & 1 & & & & \\
\hline INCM & 0.1912 & 0.1217 & -0.0446 & 0.1927 & 0.3472 & 0.4832 & 1 & & & \\
\hline LNAGE & 0.0807 & 0.0142 & -0.0367 & 0.2024 & 0.0508 & 0.1291 & 0.1726 & 1 & & \\
\hline SIZE & 0.0851 & -0.0806 & -0.3177 & 0.2023 & 0.1814 & 0.04 & -0.0662 & 0.155 & 1 & \\
\hline INFL & -0.0911 & 0.0558 & -0.0043 & 0.058 & -0.099 & -0.0504 & -0.0575 & -0.0974 & 0.214 & 1 \\
\hline
\end{tabular}

Table 3. Effect of Leverage on Working Capital

\begin{tabular}{|l|l|l|l|l|l|l|}
\hline & $(1)$ & $(2)$ & $(3)$ & $(4)$ & $(5)$ & 6 \\
\hline VARIABLES & LNWC & LNWC & LNWC & LNWC & LNWC & GMM \\
\hline & & & & & & \\
\hline LEVE & $-0.379^{* * *}$ & $-1.561^{* * *}$ & $-2.967^{* * *}$ & $-0.366^{* * *}$ & $-0.296^{* *}$ & $-0.379^{* * *}$ \\
\hline & $(0.129)$ & $(0.334)$ & $(0.516)$ & $(0.128)$ & $(0.137)$ & $(0.140)$ \\
\hline DEBTR & $-0.00322^{* *}$ & $-0.00250^{*}$ & -0.00217 & $-0.00323^{* *}$ & $-0.00320^{* *}$ & $-0.00322^{* *}$ \\
\hline & $(0.00150)$ & $(0.00149)$ & $(0.00148)$ & $(0.00150)$ & $(0.00150)$ & $(0.00128)$ \\
\hline INT & $-0.738^{* *}$ & $-0.646^{* *}$ & $-0.532^{*}$ & 0.982 & $-0.715^{* *}$ & $-0.738^{* *}$ \\
\hline & $(0.307)$ & $(0.303)$ & $(0.302)$ & $(0.928)$ & $(0.306)$ & $(0.330)$ \\
\hline DIVIPO & $1.915^{* * *}$ & $1.615^{* * *}$ & $1.385^{* * *}$ & $1.831^{* * *}$ & $2.270^{* * *}$ & $1.915^{* * *}$ \\
\hline & $(0.306)$ & $(0.312)$ & $(0.315)$ & $(0.308)$ & $(0.370)$ & $(0.308)$ \\
\hline INCM & $0.357^{* *}$ & $0.427^{* * *}$ & $0.465^{* * *}$ & $0.393^{* *}$ & $0.385^{* *}$ & $0.357^{* * *}$ \\
\hline & $(0.153)$ & $(0.152)$ & $(0.150)$ & $(0.153)$ & $(0.153)$ & $(0.138)$ \\
\hline LNAGE & 0.682 & 0.622 & 0.572 & 0.548 & 0.743 & 0.682 \\
\hline & $(0.465)$ & $(0.459)$ & $(0.454)$ & $(0.468)$ & $(0.465)$ & $(0.473)$ \\
\hline SIZE & 0.00776 & 0.0574 & 0.116 & 0.0233 & 0.0234 & 0.00776 \\
\hline
\end{tabular}




\begin{tabular}{|l|l|l|l|l|l|l|}
\hline & $(0.122)$ & $(0.121)$ & $(0.120)$ & $(0.121)$ & $(0.122)$ & $(0.120)$ \\
\hline INFL & -3.199 & -3.100 & -2.348 & -2.467 & -2.732 & -3.199 \\
\hline & $(3.749)$ & $(3.699)$ & $(3.662)$ & $(3.757)$ & $(3.752)$ & $(3.657)$ \\
\hline LEVE2 & & $0.0898^{* * *}$ & $0.467^{* * *}$ & & & \\
\hline & & $(0.0235)$ & $(0.109)$ & & & \\
\hline LEVE3 & & & $-0.0186^{* * *}$ & & & \\
\hline & & & $(0.00526)$ & & & \\
\hline LEVE x INT & & & & $-2.614^{*}$ & & \\
\hline & & & & $(1.332)$ & & \\
\hline LEVE x DIVIPO & & & & & $-0.619^{*}$ & \\
\hline & & & & & $0.365)$ & \\
\hline Constant & $1.965^{*}$ & $2.587^{* *}$ & $2.991^{* * *}$ & $2.018^{*}$ & 1.666 & $1.965^{*}$ \\
\hline & $(1.148)$ & $(1.145)$ & $(1.137)$ & $(1.145)$ & $(1.160)$ & $(1.120)$ \\
\hline & & & & & & \\
\hline Observations & 510 & 510 & 510 & 510 & 510 & 510 \\
\hline R-squared & 0.173 & 0.196 & 0.216 & 0.179 & 0.177 & 0.173 \\
\hline
\end{tabular}

Standard errors in parentheses

$* * * \mathrm{p}<0.01, * * \mathrm{p}<0.05, * \mathrm{p}<0.1$

Table 4. Effect of Leverage on Working Capital and Cash Holdings - Domestic Firms

\begin{tabular}{|l|l|l|l|l|l|}
\hline & $(1)$ & $(2)$ & $(3)$ & $(4)$ & $(5)$ \\
\hline & & & & & \\
\hline LEVE & & & & & \\
\hline & $-0.378^{* * *}$ & $-0.850^{* * *}$ & $-0.736^{* * *}$ & $-2.308^{* * *}$ & $4.759^{* *}$ \\
\hline DEBTR & $(0.122)$ & $(0.254)$ & $(0.270)$ & $(0.389)$ & $(2.344)$ \\
\hline & $-0.00271^{*}$ & 0.00266 & 0.00266 & 0.00377 & 0.000646 \\
\hline DIVIPO & $(0.00143)$ & $(0.00298)$ & $(0.00298)$ & $(0.00291)$ & $(0.00308)$ \\
\hline & $1.963 * * *$ & 0.188 & 0.691 & -0.479 & -0.220 \\
\hline INCM & $(0.312)$ & $(0.649)$ & $(0.767)$ & $(0.646)$ & $(0.667)$ \\
\hline & $0.574^{* * *}$ & $3.404 * * *$ & $3.445^{* * *}$ & $2.388^{* * *}$ & $3.495^{* * *}$ \\
\hline LNAGE & $(0.153)$ & $(0.318)$ & $(0.320)$ & $(0.374)$ & $(0.319)$ \\
\hline & $1.312^{* * *}$ & $1.668^{*}$ & $1.787 *$ & 1.541 & 1.582 \\
\hline SIZE & $(0.483)$ & $(1.006)$ & $(1.010)$ & $(0.978)$ & $(1.000)$ \\
\hline & 0.0835 & 0.389 & 0.407 & $0.457^{*}$ & $1.037 * * *$ \\
\hline INFL & $(0.130)$ & $(0.271)$ & $(0.271)$ & $(0.264)$ & $(0.381)$ \\
\hline & -3.021 & -0.564 & 0.221 & -1.320 & 1.085 \\
\hline LEVE x DIVIPO & $(4.078)$ & $(8.486)$ & $(8.505)$ & $(8.248)$ & $(8.461)$ \\
\hline & & & -0.893 & & \\
\hline LEVE x INCM & & & $(0.727)$ & & \\
\hline & & & & $1.551^{* * *}$ & \\
\hline LEVE x SIZE & & & & $(0.320)$ & \\
\hline & & & & & $-1.042^{* *}$ \\
\hline Constant & 0.666 & $-4.317^{*}$ & $-4.756^{*}$ & -3.263 & $-7.554^{* * *}$ \\
\hline & $(1.244)$ & $(2.589)$ & $(2.612)$ & $(2.525)$ & $(2.903)$ \\
\hline & & & & & \\
\hline Observations & 389 & 389 & 389 & 389 & 389 \\
\hline R-squared & 0.258 & 0.289 & 0.292 & 0.330 & 0.299 \\
\hline
\end{tabular}

Standard errors in parentheses

$* * * \mathrm{p}<0.01, * * \mathrm{p}<0.05, * \mathrm{p}<0.1$ 
Table 5. Effect of Leverage on Working Capital and Cash Holdings - International Firms

\begin{tabular}{|l|l|l|l|l|l|}
\hline & $(1)$ & $(2)$ & $(3)$ & $(4)$ & $(5)$ \\
\hline & & & & & \\
\hline & & & & & \\
\hline & $-3.257^{*}$ & $-0.560^{* * *}$ & $-0.240^{*}$ & $-0.557^{* * *}$ & -0.201 \\
\hline DEBTR & $(1.704)$ & $(0.0895)$ & $(0.131)$ & $(0.0905)$ & $(0.413)$ \\
\hline & -0.0266 & -0.00168 & -0.00120 & -0.00169 & -0.00155 \\
\hline DIVIPO & $(0.0328)$ & $(0.00172)$ & $(0.00166)$ & $(0.00173)$ & $(0.00173)$ \\
\hline & 0.622 & -0.0510 & $0.340^{* *}$ & -0.0494 & -0.0354 \\
\hline INCM & $(0.932)$ & $(0.0489)$ & $(0.130)$ & $(0.0494)$ & $(0.0520)$ \\
\hline & $-1.340^{* *}$ & $0.205^{* * *}$ & $0.222^{* * *}$ & 0.164 & $0.209^{* * *}$ \\
\hline LNAGE & $(0.585)$ & $(0.0307)$ & $(0.0299)$ & $(0.147)$ & $(0.0310)$ \\
\hline & -0.518 & $-0.239^{* * *}$ & $-0.241^{* * *}$ & $-0.232^{* * *}$ & $-0.241^{* * *}$ \\
\hline SIZE & $(1.457)$ & $(0.0765)$ & $(0.0734)$ & $(0.0806)$ & $(0.0766)$ \\
\hline & -0.231 & 0.0197 & $0.0379^{* *}$ & 0.0178 & 0.0553 \\
\hline INFL & $(0.305)$ & $(0.0160)$ & $(0.0163)$ & $(0.0174)$ & $(0.0430)$ \\
\hline & -0.413 & -0.0627 & -0.0577 & -0.0611 & -0.0605 \\
\hline LEVE x DIVIPO & $(0.810)$ & $(0.0425)$ & $(0.0408)$ & $(0.0431)$ & $(0.0426)$ \\
\hline & & & $-0.542^{* * *}$ & & \\
\hline LEVE x INCM & & & $(0.168)$ & & \\
\hline & & & & 0.0571 & \\
\hline LEVE x SIZE & & & & $(0.199)$ & \\
\hline & & & & & -0.0552 \\
\hline Constant & $7.452^{* * *}$ & $0.297 * *$ & -0.0854 & $0.296^{* *}$ & $(0.0619)$ \\
\hline & $(2.592)$ & $(0.136)$ & $(0.177)$ & $(0.137)$ & $(0.305)$ \\
\hline & & & & & \\
\hline Observations & 115 & 115 & 115 & 115 & 115 \\
\hline R-squared & 0.151 & 0.436 & 0.487 & 0.437 & 0.441 \\
\hline
\end{tabular}

Standard errors in parentheses

$* * * \mathrm{p}<0.01, * * \mathrm{p}<0.05, * \mathrm{p}<0.1$

\section{Conclusion}

Effect of financial leverage on working capital management efficiency and it replica effect on profitability cannot be overlooked. Every organization has a debts (borrowing) component as part of it resources to efficiently run the firm. Poor management of the borrowed component directly and directly affects the smooth running of the firm, at the end shareholders' funds are underutilized and consequently dividends are not paid. Both financial leverage and working capital management play key role in the success and continuity of every leverage firm. This study examines the effect of financial leverage on working capital management efficiency of non-financial firms listed in Nigeria and Ghana stock market. From the analysis it was revealed that there is significant negative relationship between financial leverage and working capital. An increase in leverage reduces the efficiency of working capital management of firms in both countries are seen to be overleverage. Therefore, mismanagement of borrowed funds as part of the capital structure of firms will hinder the effective and efficient working capital management consequently affecting the company value. The result of the study shows that there is an S-curve relationship between financial 
leverage and working capital management. Also there is a significant moderating effect of internationalization and dividend payout. This implies that firms that are involved in the international activities are highly concern with having borrowing as part of their capital structure than solely operating with owners' capital which might be the case of most domestic firms. International firms have many external sources of funds which are being utilize for growth and profitability. They are exposed to divers' resources, knowledge and capability which enhance their effectiveness and efficiency in resource management. Internationalization position the firm in having accessing to divers funds either by government of other international operating bodies for expansion and employment offering in the case of developing and less developed economies.

The effect of financial leverage on working capital and cash holdings with moderating effect of income level, size and dividend payout were examined in both international and domestic firms. From the study it was discovered that in domestic and international firms, there is a strong significant negative relationship between financial leverage and working capital management. This shows international and domestic firms in these countries access external funds in running their operational activities. It could be seen that, firms in these countries are highly leverage. Income level and size significantly moderate the relationship of financial leverage and cash holdings. The outlook of firms involved in international activities produced a different result, dividend payout moderates the relationship between financial leverage and cash holdings. This is true because the more international firms pay dividend the more attractive they become to foreign and local investors. Dividend payment has been one of the key issues of listed firms coupled with EPS and market capitalization.

The discovering of this study is useful for domestic, international firms and firms considering internationalization as part of their market development strategies. Thus, firms in both developing and less developed could have policy in place for proper management of borrowed funds and working capital. Therefore, financial managers must come out with the right combination of owners' and borrowed funds for optimal capital structure level for the maximization of shareholders' wealth. Although, this study has contributed to the area of accounting and financial research, nevertheless it encountered some limitation with data to cover all firms in Nigeria and Ghana. Due to that it was limited to only non-financial listed firms in both countries. Therefore, future research should extend to other developing and less developed economy for better generalization of discovering/findings.

\section{References}

Afza, T., \& Nazir, M. S. (2007). Is it better to be aggressive or conservative in managing working capital?. Journal of Quality and Technology Management, III(II), 11-21.

Aktas, N., Croci, E., \& Petmezas, D. (2015). Is working capital management value-enhancing? Evidence from firm performance and investments. Journal of Corporate Finance, 30(1), 98-113. https://doi.org/10.1016/j.jcorpfin.2014.12.008

Al-najjar, B., \& Belghitar, Y. (2011). Corporate Cash Holdings and Dividend Payments : Evidence from Simultaneous Analysis. Managerial and decision Economics, 241, 231-241. 
https://doi.org/10.1002/mde.1529

Al-najjar, B., \& Clark, E. (2017). Research in International Business and Finance Corporate governance and cash holdings in MENA : Evidence from internal and external governance practices. Research in International Business and Finance, 39, 1-12.

https://doi.org/10.1016/j.ribaf.2016.07.030

Altaf, N., \& Shah, F. A. (2016). Humanities and Social Sciences Internationalization and fi rm performance of Indian firms: Does product diversity matter?. Pacific Science Review A: Natural Science and Engineering, 1(2), 76-84. https://doi.org/10.1016/j.psrb.2016.05.002

Angulo-Ruiz, F., Pergelova, A., \& Wei, W. X. (2019). How does home government influence the internationalization of emerging market firms? The mediating role of strategic intents to internationalize. International Journal of Emerging Markets, 14(1), 187-206.

https://doi.org/10.1108/IJoEM-08-2017-0274

Bae, J., Kim, S., \& Oh, H. (2016). Taming Polysemous Signals: The Role of Marketing Intensity on the Rela- tionship between Financial Leverage and Firm Performance. Review of Financial Economics. https://doi.org/10.1016/j.rfe.2016.12.002

Baños-Caballero, S., García-Teruel, P. J., \& Martínez-Solano, P. (2014).Working capital management, corporate performance, and financial constraints. Journal of Business Research, 67(3), 332-338. https://doi.org/10.1016/j.jbusres.2013.01.016

Boissay, F., \& Gropp, R. (2013). Payment defaults and inter-firm liquidity provision. Review of Finance, 17(6), 1853-1894. https://doi.org/10.1093/rof/rfs045

Boubakri, N., \& Saffar, W. (2016). Culture and externally fi nanced fi rm growth. Journal of Corporate Finance. https://doi.org/10.1016/j.jcorpfin.2016.04.003.

Braun, M., \& Larrain, B. (2005). Finance and the business cycle: international, inter-industry evidence. The Journal of Finance, 60(3), 1097-1128.

https://doi.org/10.1111/j.1540-6261.2005.00757.x

Bundesbank, D. et al. (2013). Changing forces of gravity: how the crisis affected international banking. Discussion Paper, Deutsche Bundesbank, 48/2013.

Cai, J., \& Zhang, Z. (2011). Leverage change , debt overhang, and stock prices. Journal of Corporate Finance, 17(3), 391-402. https://doi.org/10.1016/j.jcorpfin.2010.12.003

Casey, E., \& O'Toole, C. M. (2014). Bank lending constraints, trade credit and alternative financing during the financial crisis: Evidence from European SMEs. Journal of Corporate Finance, 27, 173-193. https://doi.org/10.1016/j.jcorpfin.2014.05.001

Chen, C., \& Kieschnick, R. (2018). Bank credit and corporate working capital management. Journal of Corporate Finance, 48, 579-596. https://doi.org/10.1016/j.jcorpfin.2017.12.013

Connelly, J. T., Limpaphayom, P., \& Nagarajan, N. J. (2012). Form versus substance: The effect of ownership structure and corporate governance on firm value in Thailand. Journal of Banking and Finance, 36(6), 1722-1743. https://doi.org/10.1016/j.jbankfin.2012.01.017 
Coricelli, F., Driffield, N., Pal, S., \& Roland, I. (2012). When does leverage hurt productivity growth? A firm-level analysis. Journal of international Money and Finance, 31(6), 1674-1694. https://doi.org/10.1016/j.jimonfin.2012.03.006

Corugedo, E. F., McMahon, M. F., Millard, S., \& Rachel, L. (2011). Understanding the macroeconomic effects of working capital in the United Kingdom.

Dalci, I., \& Ozyapici, H. (2018). Working capital management policy in health care: The effect of leverage. Health Policy, 122(11), 1266-1272.

https://doi.org/10.1016/j.healthpol.2018.09.012

Einarsson, T., \& Marquis, M. H. (2001). Bank intermediation over the business cycle. Journal of Money, Credit and Banking, 876-899. https://doi.org/10.2307/2673927

Enqvist, J., Graham, M., \& Nikkinen, J. (2014). The impact of working capital management on firm profitability in different business cycles: Evidence from Finland. Research in International Business and Finance, 32, 36-49. https://doi.org/10.1016/j.ribaf.2014.03.005

Ebel Ezeoha, A. (2008). Firm size and corporate financial-leverage choice in a developing economy: Evidence from Nigeria. The Journal of Risk Finance, 9(4), 351-364.

https://doi.org/10.1108/15265940810895016

Ferreira, M. A., \& Vilela, A. S. (2004). Why do firms hold cash? Evidence from EMU countries. European Financial Management, 10(2), 295-319.

https://doi.org/10.1111/j.1354-7798.2004.00251.x

Hill, M. D., Kelly, G. W., \& Highfield, M. J. (2010). Net operating working capital behavior: a first look. Financial management, 39(2), 783-805.

https://doi.org/10.1111/j.1755-053X.2010.01092.x

Gill A (2015) Determinants of Corporate Cash Holdings: Evidence from Canada Determinants of Corporate Cash Holdings : Evidence from Canada. International Journal of Economics and Finance, 4(1), 70-79. https://doi.org/10.5539/ijef.v4n1p70

Gill, A. S., \& Biger, N. (2013). The impact of corporate governance on working capital management efficiency of American manufacturing firms. Managerial Finance, 39(2), 116-132. https://doi.org/10.1108/03074351311293981

Goel, U., Chadha, S., \& Sharma, A. K. (2015). Operating liquidity and financial leverage: Evidences from Indian machinery industry. Procedia - Social and Behavioral Sciences, 189, 344-350. https://doi.org/10.1016/j.sbspro.2015.03.230

Gombola, M. J., Ho, A. Y., \& Huang, C. (2015). The effect of leverage and liquidity on earnings and capital management: Evidence from U.S. Commercial banks. International Review of Economics and Finance, 43, 35-58. https://doi.org/10.1016/j.iref.2015.10.030

Guney, Y., Ozkan, A., \& Ozkan, N. (2007). International Evidence on the Non-Linear Impact of Leverage on Corporate International evidence on the non-linear impact of leverage on corporate cash holdings. Journal of Multinational Financial Management, 17. 
https://doi.org/10.1016/j.mulfin.2006.03.003

Mathuva, D. M. (2014). An empirical analysis of the determinants of the cash conversion cycle in Kenyan listed non-financial firms. Journal of Accounting in Emerging Economies, 4(2), 175-196. https://doi.org/10.1108/JAEE-10-2011-0045

Mun, S. G., \& Jang, S. C. S. (2015). Working capital, cash holding, and profitability of restaurant firms. International Journal of Hospitality Management, 48, 1-11.

https://doi.org/10.1016/j.ijhm.2015.04.003

Paniagua, J., Rivelles, R., \& Sapena, J. (2018). Corporate governance and fi nancial performance: The role of ownership and board structure. Journal of Business Research, 89, 229-234. https://doi.org/10.1016/j.jbusres.2018.01.060

Sivathaasan, N. et al. (2016). Stock liquidity, corporate governance and leverage: New panel evidence. Pacific-Basin Finance Journal. https://doi.org/10.1016/j.pacfin.2016.11.004

Tsuruta, D. (2019). Working Capital Management during the Global Financial Crisis: Evidence from Japan. Japan \& The World Economy.

https://doi.org/10.1016/j.japwor.2019.01.002

Ukaegbu, B. (2014). The significance of working capital management in determining firm profitability: Evidence from developing economies in Africa. Res Int. Bus Finance, 31, 1-16. https://doi.org/10.1016/j.ribaf.2013.11.005

Vithessonthi, C., \& Tongurai. J. (2015). The Effect of Leverage on Performance: Domestically-Oriented vs. Internationally-Oriented Firms. Research in International Business and Finance. https://doi.org/10.1016/j.ribaf.2015.02.016

\section{Copyright Disclaimer}

Copyright for this article is retained by the author(s), with first publication rights granted to the journal.

This is an open-access article distributed under the terms and conditions of the Creative Commons Attribution license (http://creativecommons.org/licenses/by/3.0/). 